\title{
POTENSI AKULTURASI BUDAYA DALAM MENUNJANG KUNJUNGAN WISATAWAN DI KOTA SEMARANG
}

\author{
Syaiful Ade Septemuryantoro
}

\author{
syaiful.ade@dsn.dinus.ac.id \\ Universitas Dian Nuswantoro
}

\begin{abstract}
Semarang as a multicultural city which there is a mixture of three ethnics groups, namely Javanese ethnics, Arab ethnics and Chinese ethnics. Semarang has a cultural acculturation that comes from three etnics. Semarang has a special food called "Lunpia". Semarang has a variety of festival's such as the Chinese New Year, Cheng Ho Festival, Dugderan Festival. One example: Dugderan festival is held welcoming ramadhan. Warag ngendog is a mythological animal with carrying eggs on its back, this creature celebrated during the dugderan festival held annualy a few days before the Ramadhan. Represent three different etnics groups in Semarang city is a Javanese ethnics, Arabian ethnics, and Chinese ethnics. Its head is like a dragon, the body is the combination of camel and the legs is teh combination of goat. Gambang Semarang is one of traditional dance in Semarang. Gambang Semarang dance is showed to be enjoyed from its moving, appearance and rhythm and the dance is a reflection of someone action which enjoy their life, joyful and thankfull to God (Allah SWT), because we have been given grace through beautiful dance. Gambang Semarang dance using gamelan instrument including Kendang, kempul, bonang, gong, kecrek and tohyan (chinese). Song in Gambang Semarang dance exhivition feels happy and fresh, in January 2020 tourist arrivals in Semarang decreased until 6 percen, because in Jauary is not a period holiday (low season period). Ahmad Yani International Airport in Semarang $i$ sthe entrance point for foreign. In January 2020, Malaysia were the highest number of tourist in Semarang (849people), Singapore (279 people) and Chinese (113 people).
\end{abstract}

Keywords: cultural, acculturation, food, festival

Ketika abad ke-15 ada seorang tokoh yang menyebarkan agama Islam bernama Ki Ageng Pandanaran. Ki Ageng Pandanaran menyebarkan agama Islam di daerah pragota kata-kata di Semarang. Pragota yang sekarang lebih dikenal dengan dengan wilayah bergota. Bergota merupakan salah satu bagian dari wilayah kerajaan Mataram, saat ini Bergota tumbuh menjadi daerah yang dapat dikatakan subur karena terdapat banyak pepohonan yang rimbun dan rumput yang tumbuh dengan lebat. Wilayah yang mempunyai pepohonan yang rimbun tersebut tumbuh suatu pohon yang dinamakan asam karena jaraknya yang terlalu jauh (arang) oleh sebab itu Ki Ageng Pandanaran menamakan asem arang atau Semarang dari kata asem itu adalah 
Syaiful Ade Septemuryantoro, Potensi Akulturasi Budaya dalam Menunjang Kunjungan Wisatawan di Kota Semarang

pohon dan arang itu yang artinya jarang. Pada saat ini kota Semarang tumbuh menjadi kota metropolitan yang menjadikan kawasan Semarang sebagai pusat ibu kota Jawa Tengah.

Semarang lebih dikenal dengan istilah kota Lunpia yang merupakan satu makanan khas yang menjadi saksi bisu perubahan zaman dari awal kerajaan Hindu Budha kemudian tumbuh pada zaman kerajaan Islam serta zaman kolonial Belanda sampai dengan penjajahan Kolonial Jepang. Pada setiap tanggal 15 Oktober Semarang mengadakan peringatan pertempuran 5 hari Semarang yang menjadi menjadi saksi bahwa Pemuda ada di Semarang mempunyai tekad untuk mempertahankan kemerdekaan. Adanya pertempuran 5 hari di Semarang maka dibangunlah sebuah tugu yang sekarang dinamakan Tugu Muda. Tugu Muda ini terletak persis di antara bangunan Lawang Sewu dengan Universitas Dian Nuswantoro Semarang. Saat ini kota Semarang menjadi salah satu destinasi dari pariwisata yang ada di Indonesia, hal ini dikarenakan kota Semarang memiliki akses yang sangat baik yaitu berada di tengah antara Jawa Barat dan Jawa Timur. Mempunyai bandara internasional Ahmad Yani yang menjadi gerbang keluar masuknya wisatawan yang akan berkunjung ke kota Semarang. Karena posisi dan letak strategis itu pula maka pertumbuhan ekonomi Jawa Tengah khususnya kota Semarang meningkat.

Saat ini kota Semarang menjadi kota yang metropolitan dengan julukan sebagai kota akulturasi budaya atau bisa dikatakan Semarang sebagai kota multikultur.

\section{PERMASALAHAN AKULTURASI BUDAYA DI ERA GLOBALISASI}

Era globalisasi yang mengubah zaman menjadikan kebudayaan dianggap ketinggalan zaman oleh masyarakat saat ini. Ada sebagian dari masyarakat yang masih tetap mempertahankan serta mentradisikan salah satu peninggalan nenek moyang. Kebudayaan baru yang dianggap sebagai kebudayaan modern menjadikan warisan nenek moyang lambat laun akan tergerus seiring perkembangan zaman. 
Kebudayaan merupakan pencerminan dari nilai, keyakinan, pandangan, ide yang umumnya mempunyai komunitas, sehingga dapat diartikan sebagai jati diri masyarakat. (Koentjaraningrat, 2009).

Masuknya globalisasi yang menggerus kebudayaan sehingga menyebabkan budaya tersebut ketinggalan zaman meskipun dari sebagian masyarakat tetap menjunjung tinggi kebudayaan peninggalan nenek moyangnya masyarakat lambat laun mulai meninggalkan budaya nenek moyang sehingga muncul kebudayaan yang baru yang merupakan budaya modern. Kebudayaan merupakan nilai refleksi pandangan keyakinan kebutuhan maupun gagasan yang diyakini oleh beberapa komunitas yang menjadi di simbol dalam akulturasi budaya. Budaya ini merupakan jati diri dari suatu kebudayaan masyarakat yang tercipta dari hasil kegiatan maupun penciptaan akal budi manusia seperti adat istiadat kepercayaan maupun kesenian manusia bisa dikatakan sebagai makhluk sosial yang secara secara keseluruhan digunakan untuk memahami konsep kehidupan yang ada di masyarakat. Perlu adanya sosialisasi dan pengenalan warisan budaya nenek moyang kepada generasi selanjutnya.

Manusia sebagai makhluk personal yang menjadi pelaku dari kebudayaan yang ada di kota Semarang sehingga berpola dan membentuk satu akulturasi budaya seperti halnya mitologi warak ngendog. Warak ngendog adalah tradisi dugderan yang setiap menjelang bulan Ramadhan selalu dilakukan sampai dengan saat ini. Festival dugderan tetap dipertahankan karena merupakan sosial kultural yang ada di tengah masyarakat kota, dalam hal ini warak ngendog juga menjadi maskot wisata kota Semarang. Sosial kultural masyarakat kota Semarang. Menurut Badan Pusat Statistik (2020) tercatat bahwa kota Semarang termasuk masyarakat yang religius dengan agama Islam sebagai agama mayoritas penduduk kota Semarang yaitu sebanyak 1.3 juta jiwa, sementara itu julukan kota yang religius terbukti terdapat enam agama yang ada di kota Semarang antara lain agama Islam, agama Kristen, agama Katolik, agama Hindu, agama Budha dan agama Khonghucu. Setiap individu memeluk kepercayaan masing-masing berdasarkan dari warisan turun-temurun nenek moyang sehingga kota 
Syaiful Ade Septemuryantoro, Potensi Akulturasi Budaya dalam Menunjang Kunjungan Wisatawan di Kota Semarang

Semarang merupakan salah satu kota yang dijadikan objek penyebaran agama. Mayoritas penduduk kota Semarang beragama Islam yang dibawa oleh pedagang Melayu kota Semarang didirikan oleh seorang pemuda bernama Ki Pandan Arang pada tahun 1476 M. Kyai Pandanaran atau Kyai Pandan Arang merupakan pendiri kota Semarang dan Bupati Semarang yang pertama. Ki Pandan Arang diberikan izin oleh Kesultanan Demak untuk mendirikan wilayah yang ada di sebelah Barat yang sekarang sering disebut dengan kota Semarang. Masyarakat Semarang yang mempunyai kehidupan beragam yang beragam tentunya memiliki ritual keagamaan yang tetap dilaksanakan sebagai tradisi dari masyarakat. Umumnya ritual yang diadakan oleh masyarakat kota Semarang merupakan warisan turun-temurun nenek moyang dan dikaitkan dengan agama yang dianut oleh beberapa etnis yang ada di kota Semarang, sehingga menjadikan kota Semarang sebagai kota akulturasi multikultural.

Semarang menjadi kota persinggahan karena letaknya yang sangat strategis di antara Jawa Barat dan Jawa Timur serta pendatang dari negara asing kita bisa melihat keberagaman etnis yang ada di kota Semarang dengan melihat adanya pemukiman di wilayah Pecinan dan Pedamaran. Pecinan dan Pedamaran berada di sekitar Gang Pinggir sampai dengan jalan Mataram dulunya merupakan pemukiman yang didirikan oleh pedagang dari Cina. Pada saat Laksamana Cheng Ho mendarat di kota Semarang membawa agama Islam untuk diajarkan di masyarakat Tionghoa Semarang, selain Cina terdapat pedagang muslim Melayu yang juga mendirikan pemukiman di Kampung Melayu dan Kampung darat yang ada di kawasan Kauman Semarang, ada juga wilayah Pakojan yang ada di kawasan jalan Kauman sampai dengan jalan Wahid Hasyim ini merupakan tempat pemukiman orang muslim yang berasal dari Arab, India, Pakistan, dan Persia. Ketika zaman yang telah berubah menjadi zaman modern tentunya menjadikan kota Semarang sebagai kota akulturasi multikultural dan multi etnis. 
Letak keberadaan Semarang yang ada di pesisir Jawa menjadikan kota Semarang sebagai kota multikultural budaya lokal maupun budaya etnis yang menjadikan kota Semarang sebagai kota akulturasi, dalam hal ini bisa dilihat dalam beberapa aktivitas atau upacara oleh masyarakat pesisir terutama demi mendapatkan keselamatan dan rezeki yang melimpah, antara lain adanya sedekah laut yang dilakukan oleh nelayan yang bermukim di Tambak Lorok dan daerah Bandarharjo. Penduduk muslim di kota Semarang tentunya tetap mempertahankan tradisi keagamaan yang tetap diselenggarakan sampai dengan saat ini.

Tradisi yang masih dijalankan sampai saat ini antara lain tasyakuran, tahlilan, yasinan, khataman, berjanji, manakiban, takbiran, serta dugderan yang kesemuanya tetap dilestarikan sampai dengan saat ini. Selain agama Islam adat tradisi ritual yang dilakukan oleh etnik Tionghoa yang bermukim di kota Semarang seperti festival Dewa bumi, perayaan Tahun Baru Imlek, kemudian festival Sam Poo Kong sampai dengan larung sesaji yang ditujukan untuk Dewa Samudra. Selain itu ada salah satu festival yang dilakukan di kota Semarang yaitu dugderan salah satunya adalah mengangkat mitos atau hewan mitologi yang berasal dari 3 etnis yaitu etnis Jawa etnis Tionghoa dan etnis Arab sehingga dijadikan sebagai simbol akulturasi harmonisasi kehidupan yang ada di kota Semarang, sehingga membentuk budaya yang beragam.

Tradisi dugderan umumnya dilakukan menjelang bulan suci Ramadhan. Masyarakat selalu memperingati dan melaksanakan kegiatan dugderan setiap tahunnya. Kegiatan dugderan tersebut sudah berlangsung sejak pemerintahan Bupati KRMT Purbaningrat pada tahun 1881 M. Festival arak-arakan yang diselenggarakan guna menyambut datangnya bulan puasa sesaat sebelum menjelang bulan suci Romadhan tepatnya satu hari sebelumnya setelah salat Asar dan sebagai simbol maka dipukulah bedug masjid Kauman dengan menggunakan pemukul, sedangkan di halaman pendopo Kanjengan di sulut meriam sehingga mengeluarkan bunyi Dug yang berasal dari produk serta bunyi Der yang berasal dari meriam sehingga digabungkan menjadi dugderan. Karena mendengar suara dug dan der yang sangat keras yang ada di alun-alun kota Semarang atau kawasan Kauman, masyarakat 
Syaiful Ade Septemuryantoro, Potensi Akulturasi Budaya dalam Menunjang Kunjungan Wisatawan di Kota Semarang

berbondong-bondong menyaksikan apa yang terjadi di alun-alun depan masjid Kauman tersebut. Pada saat itu keluarlah KRMT Purbaningrat dan imam besar Masjid Kauman memberikan pengumuman kepada masyarakat bahwa awal bulan puasa akan berlangsung keesokan harinya serta ajakan untuk meningkatkan persatuan di antara sesama muslim maupun nonmuslim.

\section{TUJUAN PENELITIAN}

Akulturasi budaya yang ada di kota Semarang terutama ketiga etnis tersebut dipersatukan karena dahulu Belanda mengelompokkan etnis tersebut berbeda-beda seperti misalnya perkampungan Belanda yang ada di daerah Semarang atas kemudian warga Arab yang ada di daerah Pekojan dan Padamaran kemudian warga etnis Tionghoa yang ada di daerah Pecinan serta kelompokkan di Kampung Melayu dan masyarakat pribumi Jawa di Kampung Jawa, karena terjadinya perbedaan satu dengan masyarakat yang lain seperti contohnya di kalangan umat Islam dalam menentukan awal bulan puasa sehingga Bupati Purbalingga menyatukan perbedaan penentuan awal bulan puasa dan mendapatkan dukungan dari kalangan ulama yang ada di Semarang, salah satunya adalah Kyai Saleh Darat, festival dugderan menciptakan lapisan masyarakat yang berkumpul kemudian bersatu berbaur dan bertegur sapa tanpa sama sekali ada perbedaan di antara mereka, sehingga awal bulan puasa Ramadan secara serentak dilaksanakan oleh umat muslim yang ada di kota Semarang. Sehingga dalam sejarahnya dugderan pada saat itu dilaksanakan di masjid besar Kauman sehingga ritual dugderan menjadikan masjid sebagai pusat perkumpulan umat muslim. Adapun festival dugderan itu terdiri dari tiga agenda pokok yang pertama adalah pasar dug der, kemudian prosesi ritual awal puasa serta kirab budaya warak ngendog. Adapun tiga agenda tersebut sampai saat ini masih terus dilestarikan dan dilakukan untuk menyambut datangnya bulan suci Ramadhan. Adapun tujuan dari penelitian adalah sebagai berikut :

1. Mengetahui akulturasi budaya di kota Semarang

2. Mengetahui akulturasi kesenian yang ada di kota Semarang 
3. Mengetahui makanan khas akulturasi budaya di kota Semarang

4. Mengetahui kunjungan wisatawan di kota Semarang

5. Mengetahui tingkat penghunian kamar (TPK) hotel di kota Semarang

\section{AKULTURASI BUDAYA DI KOTA SEMARANG}

Terdapat bermacam akulturasi budaya yang peneliti lihat di kota Semarang. Salah satunya adalah perayaan dugderan bagi umat muslim yang ada di kota Semarang dari tahun ke tahun dipusatkan di balai kota sampai masjid besar Kauman dan saat itu rute yang dilewati adalah di jalan Pemuda kemudian berakhir di masjid Kauman yang ada di Semarang Sementara itu di masjid besar Kauman ada ulama dan Habaib yang ada di kota Semarang mengambil keputusan bahwa puasa akan dimulai keesokan harinya dengan adanya kesepakatan dari ulama maka bupati membacakan keputusan ulama bahwa esok hari akan dilakukan ibadah puasa Ramadhan setelah Bupati menyelesaikan pembacaan surat keputusan tersebut maka di Pati akan memukul bedug Kauman dan bunyi meriam yang ada di areal luar berdentum sehingga menimbulkan suara duk dan der Kemudian datang arak-arakan warak ngendog serta dari rombongan yang lainnya dengan adanya pembacaan keputusan dari Bupati ada bunyi dug dan Der membuat masyarakat merasa senang dengan suasana yang meriah dengan didengarkannya bunyi meriam dan bunyi bedug serta ada salah satu hewan mitologi yang menjadi pusat perhatian yaitu warak ngendog jadi setiap kali dugderan pasti warak ngendog menjadi simbol yang utama, terutama bagi para pedagang pasar yang umumnya menjual kerajinan ataupun warak ngendog dengan perkembangan zaman saat ini tidak lagi menggunakan meriam sehingga digunakanlah sirine yang menandai tradisi dugderan dengan adanya dugderan di areal depan masjid besar Kauman ditandai dengan adanya pedagang yang menjajakan aneka makanan minuman permainan anak gerabah dan masih banyak lagi sehingga memberikan warna yang menghiasi setiap tradisi dugderan yang dilakukan setiap tahunnya 
Syaiful Ade Septemuryantoro, Potensi Akulturasi Budaya dalam Menunjang Kunjungan Wisatawan di Kota Semarang

Warak ngendog sebagai simbol tradisi dugderan yang selalu dipusatkan di masjid besar Kauman, bersamaan dengan warak ngendog sampai di halaman masjid, bupati membacakan pengumuman mengenai awal bulan Ramadan yang disaksikan oleh masyarakat muslim dalam mendengar suara bedug maupun meriam dan pada saat itu ditampilkan salah satu ikon hewan mitologi yang menarik yang disebut dengan warak ngendog warak ngendog ini memiliki kepala yang berbentuk naga yang menggambarkan sosok yang rakus dan menakutkan badan leher kaki dan ekor ditutupi oleh bulu yang tersusun terbalik pada saat ini kerajinan warak ngendog menggunakan kertas minyak yang beraneka warna untuk menciptakan bulu yang terbalik tersebut pada tahun 1881 warak ngendog terbuat dari bahan yang sederhana seperti bambu sabut kelapa serta kayu namun seiring dengan perkembangan zaman bahan-bahan digunakan adalah kayu kertas minyak karton gabus maupun yang lain sebagainya dalam perkembangan zaman.

Penelitian terdahulu (Triyanto, 2013) menyebutkan bahwa warak ngendog sebagai akulturasi budaya pada seni rupa, sehingga dalam penelitian ini, peneliti ingin menguraikan tentang warak ngendog sebagai akulturasu budaya Jawa, budaya Cina, budaya Arab yang disatukan ke dalam makhluk mitologi yang dikenal dengan warak ngendog. Menurut Triyanto (2013) ada tiga jenis kelompok warak ngendog berdasarkan bentuk antara lain:

1. Warak ngendog klasik

Warak ngendog klasik umumnya masih menampilkan unsur serta struktur asli dari warisan turun temurun dengan bentuk kepala dan bagian mulut yang mempunyai gigi yang sangat tajam mata melotot telinga tegak memiliki tanduk mempunyai jenggot yang sangat lebat serta panjang baik badan leher maupun 4 kaki yang menyerupai kambing ditutupi oleh bulu yang terbalik berselang-seling warna merah hijau kuning putih dan biru dan warna ini mempunyai ekor yang panjang melengkung 
serta terhadap surai terdapat surai di ujungnya dengan telur maupun atau Endog yang terletak di antara dua kaki di belakang.

\section{Warak ngendog modifikasi}

Warak ngendog modifikasi hanya berbeda di bagian kepala yang memenuhi dengan naga sehingga bentuk Naga terdapat kemiripan antara Naga Jawa atau Naga Cina moncongnya yang diproyeksikan diproyeksikan seperti buaya dengan deretan gigi yang tajam lidah yang menjulur bercabang mata melotot dan berjanggut panjang dan lebat di atas kepalanya mempunyai tanduk kecil seperti Rusa kulitnya bersisik bulunya terbalik dan mempunyai surai di belakang kepala biasanya Naga Jawa itu memakai mahkota yang selalu ada di atas kepala.

\section{Warak ngendog kontemporer}

Struktur warak ngendog klasik hampir sama dengan struktur warak ngendog kontemporer hanya kepala dan bulunya tidak sesuai contohnya kepalanya menyerupai harimau bulunya tidak terbalik seperti warak ngendog yang klasik maupun tidak berbulu maupun tidak bersisik dengan melihat adanya kepala warak ngendog yang menyerupai naga yang di yang ada dalam mitos Cina sehingga warak ngendog merupakan salah satu dari wujud akulturasi budaya dari berbagai bangsa pendatang.

Warak ngendog merupakan simbol akulturasi budaya yang ada di kota Semarang dengan bentuk kepala yang berupa naga atau pilin sebagai binatang yang paling berpengaruh dan paling berkuasa di Cina tetap badan dari warak ngendog, yaitu menyerupai unta ataupun buruk yang digunakan oleh Nabi Muhammad pada saat Isra Mi'raj ada juga pendapat yang menyebutkan bahwa menurut supramono bahwa warak ngendog merupakan hadiah yang diberikan oleh etnis Tionghoa yang pada saat itu digunakan untuk memeriahkan festival memeriahkan tradisi dugderan sebagai bentuk dari wujud Kedamaian serta menebus kesalahan pada waktu membakar masjid besar pada saat itu warga Pecinan memberontak dan membakar masjid besar Kauman tetapi tidak ada dasar sehingga warak ngendog tetap diyakini 
Syaiful Ade Septemuryantoro, Potensi Akulturasi Budaya dalam Menunjang Kunjungan Wisatawan di Kota Semarang

sebagai pengaruh budaya Jawa dan budaya Islam, menurut buku Semarang tempo dulu karya Muspriyanto (2006) mengatakan bahwa salah satu pembuat warak ngendog yang ada di kota Semarang bawa dahulunya warna untuk itu adalah imajinasi sehingga diciptakanlah binatang dengan kaki empat kemudian mempunyai telinga dan punya telur dengan kepalanya berbentuk naga badan berbentuk unta dan kaki berbentuk kambing warak ngendog sebagai simbol akulturasi budaya kota Semarang warak ngendog yang menjadi ikon kota Semarang yang dapat ditemui di Jalan Pandanaran mempunyai karya seni yang sangat baik indah yang dilihat dari perpaduan antara cara tampilan kombinasi garis warna tekstur serta bentuk yang menjadikan warak ngendog tersebut sangat indah saat ini para pembuat atau pengrajin warak ngendog itu menggunakan kertas minyak yang berwarna-warni untuk membungkus dari badan warak ngendog tersebut ada juga dari tingkat ekspresinya yang digambarkan bahwa adanya kepala leher kaki dan badan tersebut memiliki unsur-unsur yang memunculkan karakter hewan yang ganas menakutkan serta rakus.

Salah satu contoh yang menjadikan akulturasi ketiga budaya tersebut adalah suatu makhluk yang menggambarkan tiga jenis etnis yang sering kita sebut dengan istilah warak ngendog warak ngendog ini mempunyai ciri khas dengan kepala yang menyerupai naga serta memiliki empat buah kaki seperti kambing sedangkan badannya menyerupai hewan unta, kepala yang menyerupai naga menggambarkan atau melambangkan budaya dari Tionghoa kemudian kaki yang berjumlah 4 menyerupai kambing melambangkan budaya dari Jawa sedangkan badan yang menyerupai hewan unta melambangkan budaya dari Arab. (Supramono, 2007)

Warak ngendog memberikan bentuk penggambaran kepada masyarakat bahwa dahulunya etnis ketiga tersebut melebur menjadi satu yang merupakan penduduk dari kota Semarang. Maskot warak ngendog ini diperkenalkan oleh Raden Pandanaran pertama kali, sehingga warak ngendog sampai saat ini dijadikan maskot kota Semarang. Festival warak ngendog dilaksanakan pada saat 1 hari sebelum pelaksanaan ibadah puasa Ramadhan. Sering digelar festival dugderan dari kata 
duduk dan modern yaitu festival yang diadakan menyambut bulan Romadhan warak ngendog ini selalu ditampilkan dalam festival tersebut jadi warak ngendog sebagai simbol toleransi akulturasi budaya multikultural antar etnis dan agama dari 3 etnis yang ada di kota Semarang antara lain etnis Arab etnis Jawa dan etnis Tiongho, warak ngendog yang dijadikan simbol saat ini dibangunlah patung di tengah-tengah kota ada di taman Pandanaran yang berada di Jalan Pandanaran.

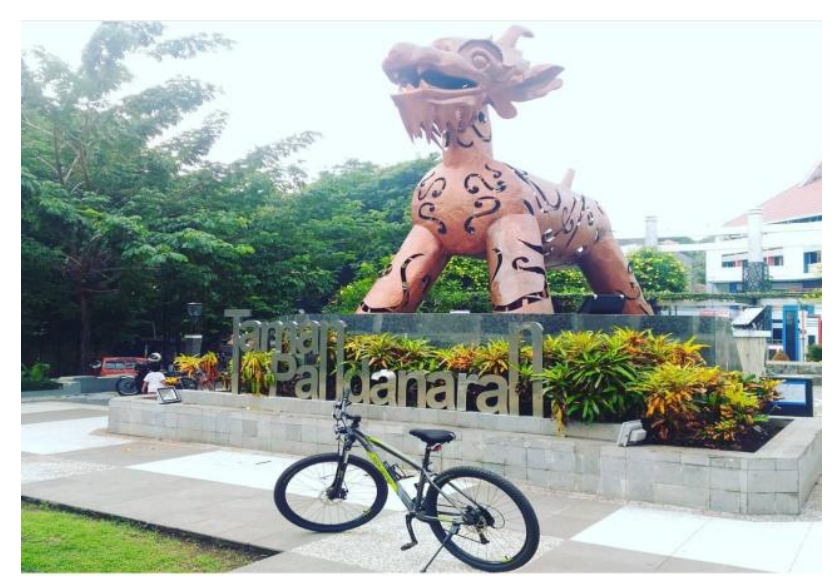

Gambar 1. Tugu Warak ngendog di Protokol Pandanaran Semarang [Sumber :dokumen pribadi]

Keberagaman atau akulturasi budaya yang ada di kota Semarang tidak pernah lepas dari agama yang berada di kota Semarang yang berasal dari beragam dari segi etnis. Adanya keberagama agama yang ada di kota Semarang tidak lepas dari penjajah yang masuk ke kota Semarang pada saat itu. Semarang mempunyai nilai historis yang sangat tinggi dengan dipenuhi oleh gedung-gedung keagamaan baik masjid gereja maupun kelenteng. Semarang juga menawarkan paket wisata religi yang tidak kalah menarik dengan wisata kulinernya seperti contoh masjid Layur. Masjid Layur berada di kawasan Kauman kota Semarang. Masjid ini menjadi saksi bisu bagaimana Agama Islam disebarkan oleh pedagang yang berasal dari Melayu yang saat itu singgah di kota Semarang, karena mempunyai nilai historis masjid Layur pernah digunakan untuk syuting dari film nasional. Selain masjid ada juga bangunan gereja yang menjadi nilai historis tinggi salah satunya yaitu gereja blenduk. 
Syaiful Ade Septemuryantoro, Potensi Akulturasi Budaya dalam Menunjang Kunjungan Wisatawan di Kota Semarang

Gereja blenduk terletak di daerah kawasan kota lama Semarang yang masih berdiri kokoh sampai dengan sekarang. Gereja dengan nama gereja Immanuel terletak di protokol Letjen Suprapto, disebut Blenduk karena kubah besar setengah lingkaran. Geraja Blenduk didirikan tahun 1973 yang dulunya sebagai gereja NEDERLANDSCHE INDISCHE KERK. Gereja Katedral Semarang yang menjadi simbol penyebaran agama Katolik di kota Semarang. Gereja Blenduk memiliki arsitektur yang baik berasal dari kata Blenduk itu yang artinya kubah yang di dalamnya terdapat ornamen-ornamen yang menggambarkan kehidupan agama Protestan yang ada di kota Semarang. (Septemuryantoro, 2017).

Etnis Tionghoa yang ada di kota Semarang merupakan salah satu etnis yang menyusun penduduk di kota Semarang. Banyak dijumpai kelenteng dan wihara yang bertuliskan tentang sejarah Tionghoa. Salah satu contoh klenteng yang ada di Semarang adalah Kelenteng Sam Poo kong. Kelenteng ini merupakan salah satu akulturasi budaya dari seseorang yang bernama Cheng Ho. Laksamana Cheng Ho merupakan muslim yang berasal dari Tiongkok, meskipun Cheng Ho beragama muslim akan tetapi beliau dihargai oleh kaum Tionghoa Semarang sehingga kaum Tionghoa membangun patung berlapis emas yang dijadikan media sembahyang etnis Tionghoa. Tujuan membangun patung Chengho untuk mendapatkan rezeki maupun keselamatan dalam hidupnya. Selain Sam Poo Kong ada klenteng Tay Kak sie ini ada di kawasan Pecinan Semarang, kelenteng ini merupakan klenteng yang terbesar yang ada di kota Semarang. Kelenteng Tay Kak sie merupakan konsep pemujaan terhadap Dewa dan Dewi dari etnis Tionghoa, mereka berkeyakinan bahwa dengan memuja dewa bisa mendatangkan rezeki maupun keselamatan dan keberkahan dalam hidupnya. (https://sampookong.co.id/, diakses 1 Maret 2020).

Vihara Buddhagaya Watugong berdiri megah 45 meter yang khusus dipersembahkan untuk Dewi Kwan In atau Dewi Welas Asih, saat ini Pagoda Buddhagaya dinobatkan sebagai pagoda Buddha tertinggi di Indonesia. Semarang tidak hanya terkenal dengan keagamaan yang ada simbol dari bangunan agama tetapi 
adanya keharmonisan budaya akulturasi yang ada di kota Semarang ditunjukkan dengan adanya festival kegiatan yang diselenggarakan kota Semarang. Karnaval yang diselenggarakan mempunyai tujuan untuk mempromosikan maupun mengenalkan budaya kepada wisatawan yang berasal dari luar kota Semarang.

Salah satu festival yang wajib didatangi atau dinikmati oleh wisatawan adalah festival dugderan. Festival ini ditujukan dalam menyambut bulan suci Ramadhan bagi masyarakat muslim yang ada di kota Semarang, selain itu juga digelar karnaval Paskah yang diselenggarakan untuk menyambut hari raya umat Nasrani. Biasanya Gereja Katedral menyelenggarakan kegiatan Paskah untuk memperingati hari raya umat Nasrani. Pasar Semawis atau lebih dikenal dengan pasar Pecinan digelar event setiap tahunnya, biasanya pasar Imlek Semawis menyelenggarakan agenda tahunan untuk menyambut tahun baru etnis Tionghoa yaitu Tahun Baru Imlek, perayaan tahun baru imlek juga ditandai dengan adanya festival barongsai. Selain menyelenggarakan Imlek terdapat satu agenda festival yang dilaksanakan untuk memperingati datangnya Laksamana Cheng Ho ke kota Semarang.

Acara Imlek ini dipusatkan pada dua kelenteng besar yaitu Klenteng Sam Poo Kong dan Klenteng Tay Kak Sie. Selain itu ada kegiatan festival atau pawai ogohogoh yang ditujukan untuk memperingati agama Siwa, hal ini tentunya dengan adanya event festival maupun karnaval lintas etnis yang ada di kota Semarang menunjukkan bahwa kota Semarang merupakan kota multikultural bagi etnis yang mendiami kota tersebut. Kota Semarang menjadi salah satu contoh dari akulturasi budaya yang melebur menjadi satu dengan harmonis sehingga dengan perputaran zaman, kota Semarang yang tidak pernah meninggalkan jati dirinya sebagai kota yang indah kota Semarang yang menjadi salah satu destinasi wisata yang ada di Indonesia, terutama wisata budaya. 
Syaiful Ade Septemuryantoro, Potensi Akulturasi Budaya dalam Menunjang Kunjungan Wisatawan di Kota Semarang

\section{KESENIAN SEBAGAI SIMBOL AKULTURASI BUDAYA}

Indonesia adalah negara yang mempunyai keanekaragaman baik suku agama ras etnis dan budaya. Keanekaragaman merupakan salah satu cermin yang mempersatukan perbedaan pada masyarakat, Kebudayaan umumnya dipengaruhi oleh kebudayaan yang dibawa oleh kolonial penjajah seperti budaya Eropa, budaya Tionghoa, budaya Arab yang menjadi satu akulturasi budaya yang membentuk suatu peradaban yang ada di kota Semarang. Salah satu budaya yang terkenal di kota Semarang adalah Gambang Semarang atau tarian Semarangan. Gambang Semarang sering diperdengarkan di tempat-tempat wisata ataupun stasiun kereta api di Semarang yang selalu memutarkan lagu Gambang Semarang untuk menyambut kedatangan wisatawan yang akan berkunjung di kota Semarang melalui dua Stasiun yaitu Stasiun Poncol dan Stasiun Tawang.

Gambang Semarang merupakan akulturasi budaya yang berasal dari etnis Jawa dengan etnis Tionghoa tetapi ciri khas Jawa lebih kental dalam gambang Semarang. Tarian Ini pertama kali diperkenalkan pada tahun 1930 yang terdiri dari perkumpulan pribumi Jawa dan Tionghoa peranakan. Gambang Semarang umumnya dipentaskan pada perayaan maupun festival. Umumnya perayaan maupun festival yang diadakan multi etnis yang ada di kota Semarang menjadikan kebudayaan yang ada di kota Semarang sebagai budaya yang dapat mempersatukan perbedaan. Seperti contohnya tradisi dugderan dan festival seni budaya. Gambang Semarang lebih dikenal dengan tarian Semarang, merupakan seni tari yang dipadukan musik dan lawak.

Kesenian ini menggunakan alat untuk mengiringi tarian tersebut antara lain antara lain Bonang, gong, suling, kempul, kendang, gambang. Selain dari pribumi Jawa terdapat alat musik khas etnis Tionghoa yaitu Toh Yan. Gerakan dari tari ini memadukan dari ekspresi Sang Penari yang menggambarkan gembira atau perasaan suka cita serta memperlihatkan lekuk gerakan pinggul seolah-olah menggambarkan gelombang laut yang ada di kota Semarang, karena kota Semarang berada di di 
pinggiran dari pantai utara Jawa sehingga memproyeksikan kesenian tersebut sebagai simbol akulturasi budaya yang ada di kota Semarang.

\section{MULTIKULTURAL MAKANAN KOTA SEMARANG}

Akulturasi budaya yang ada di kota Semarang menarik wisatawan berkunjung di kota Semarang terutama terdapat jajanan khas kota Semarang yang tidak lengkap rasanya jika berkunjung ke Semarang tidak membawa makanan tersebut, sehingga kuliner menjadi salah satu agenda wajib bagi wisatawan yang akan berkunjung di kota Semarang untuk membawa oleh-oleh tersebut ke kota asal. Lunpia Semarang adalah salah satu jenis dari multikultural kuliner yang yang berasal dari akulturasi budaya Jawa serta budaya Tionghoa awal mulanya adalah seorang pemuda keturunan Tionghoa yang menjual Lunpia yang berisi daging babi kemudian Pemuda tersebut jatuh hati kepada perempuan Jawa yang juga menjual Lunpia yang berisi cacahan Rebung atau bambu muda dan udang, 2 orang tersebut lalu menikah dan terciptalah satu kuliner baru dengan rasa yang merupakan gabungan atau campuran dari kedua warisan budaya tersebut seiring berkembangnya waktu Lunpia berisi tidak hanya udang melainkan rebung (bambu muda), ayam, telur, Lunpia kemudian dijuluki sebagai makanan khas kota Semarang, sehingga kota Semarang terkenal dengan julukan kota Lunpia. Semarang memiliki masyarakat yang beragam yang berasal dari bermacam-macam etnis terdiri dari tiga jenis etnis yang ada di kota Semarang yang pertama adalah etnis Jawa kemudian etnis Tionghoa dan juga etnis Arab. Etnis-etnis yang ada di kota Semarang hidup rukun berdampingan satu dengan yang lain yang melebur sehingga terciptanya akulturasi budaya yang ada di kota Semarang. Sehingga tak heran kita bisa menemukan kuliner maupun budaya dari ketiga etnis tersebut.

\section{POTENSI AKULTURASI BUDAYA DALAM MENUNJANG KUNJUNGAN WISATAWAN DI KOTA SEMARANG}

Analisis potensi akulturasi budaya terhadap wisata kota Semarang menunjukkan bahwa kota Semarang dengan multikultural etnis serta multikulural budaya sangat berkaitan erat dengan kunjungan wisatawan. Kenaikan jumlah hotel, jumlah kamar 
Syaiful Ade Septemuryantoro, Potensi Akulturasi Budaya dalam Menunjang Kunjungan Wisatawan di Kota Semarang

dan jumlah tempat tidur menunjukkan bahwa terjadi kenaikan kunjungan wisatawan di kota Semarang. Semakin tinggi jumlah wisatawan maka kebutuhan akomodasi untuk menunjang pariwisata di kota Semarang akan berbanding lurus dengan kenaikan jumlah hotel berbintang di kota Semarang. Menurut Badan Pusat Statistik (2020) menunjukkan bahwa terjadi kenaikan hotel berbintang dari tahun 2017 sampai tahun 2018 yang dapat dilihat pada tabel 1 dan tabel 2.

Tabel 1. Jumlah Hotel, Jumlah Kamar dan Jumlah Tempat Tidur pada Hotel Berbintang di Kota Semarang, 2017

\begin{tabular}{|c|c|c|c|c|c|c|}
\hline Hotel Berbintang & $\begin{array}{c}\text { Bintang } \\
1\end{array}$ & $\begin{array}{c}\text { Bintang } \\
2\end{array}$ & $\begin{array}{c}\text { Bintang } \\
\mathbf{3}\end{array}$ & $\begin{array}{c}\text { Bintang } \\
4\end{array}$ & $\begin{array}{c}\text { Bintang } \\
5\end{array}$ & Total \\
\hline Jumlah Hotel & 9 & 14 & 22 & 13 & 3 & 61 \\
\hline Jumlah Kamar & 505 & 1.410 & 1.749 & 2.058 & 727 & 6.446 \\
\hline Jumlah Tempat Tidur & 674 & 2.243 & 2.701 & 3.035 & 1.184 & 9.837 \\
\hline
\end{tabular}

Tabel 2. Jumlah Hotel, Jumlah Kamar dan Jumlah Tempat Tidur pada Hotel Berbintang di Kota Semarang, 2018

\begin{tabular}{lcccccc}
\hline \multicolumn{1}{c}{ Hotel Berbintang } & Bintang & Bintang & Bintang & Bintang & Bintang & Total \\
& $\mathbf{1}$ & $\mathbf{2}$ & $\mathbf{3}$ & $\mathbf{4}$ & $\mathbf{5}$ & 80 \\
\hline Jumlah Hotel & 16 & 22 & 19 & 19 & 4 & 8.182 \\
Jumlah Kamar & 771 & 1.745 & 2.132 & 2.649 & 885 & 12.387 \\
\hline
\end{tabular}

Sumber : Badan Pusat Statistik Kota Semarang, 2020: 13

Grafik 1. Perbandingan Jumlah Hotel, Jumlah Kamar dan Jumlah Tempat Tidur pada Hotel Berbintang di Kota Semarang tahun 2017 dan 2018 
91 Lก̊TE, Volume 16 Nomor 1, Maret 2020

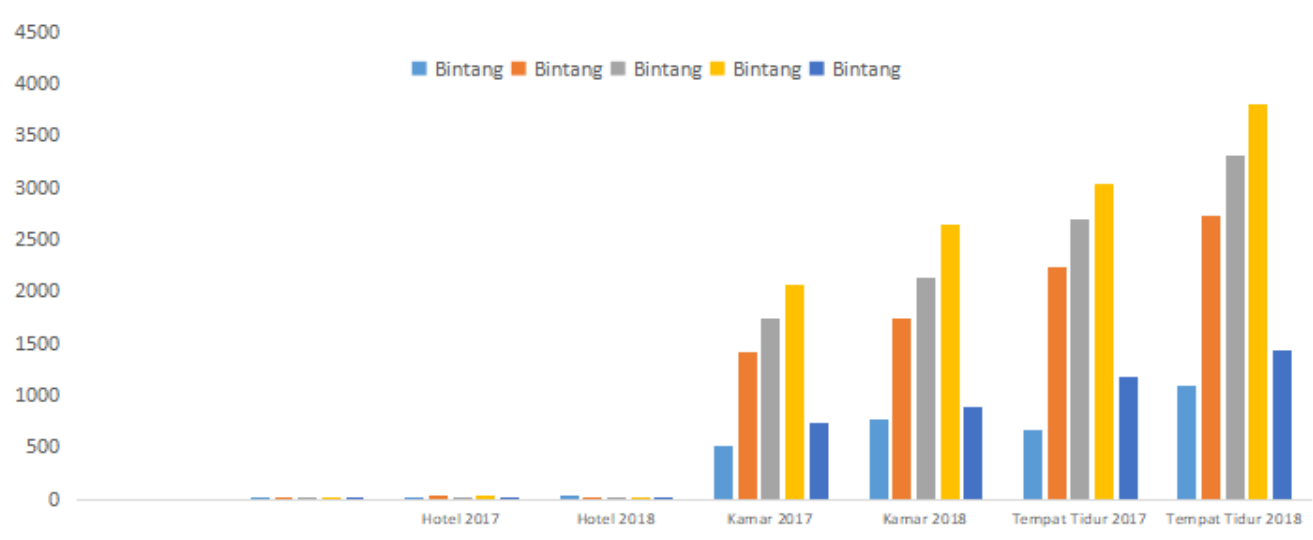

Pada grafik 1 menunjukkan bahwa terjadi kenaikan apabila dilihat dari jumlah hotel berbintang, jumlah kamar dan jumlah tempat tidur. Adanya kenaikan jumlah hotel di kota Semarang menunjukkan kenaikan jumlah wisatawan yang berkunjung di kota Semarang. Menurut Badan Pusat Statistik (2020) menyebutkan bahwa kenaikan jumlah hotel, jumlah kamar dan jumlah tempat tidur pada hotel berbintang antara 20 persen sampai 50 persen.

Tingkat Penghunian hotel berbintang di kota Semarang pada bulan Desember 2019 dan Januari 2020 dapat dilihat pada tabel 3.

Tabel 3. Tingkat Penghunian Kamar Hotel Berbintang kota Semarang periode Desember 2019. Januari 2020

[Sumber : https://semarangkota.bps.go.id/diakses 01 Maret 2020]

\begin{tabular}{|c|c|c|c|}
\hline \multirow{2}{*}{ Kelas Hotel } & \multicolumn{2}{|c|}{ TPK (\%) } & \multirow{2}{*}{$\begin{array}{l}\text { Perubahan Januari } 2020 \\
\text { terhadap Desember } 2019\end{array}$} \\
\hline & Desember 2019 & Januari 2020 & \\
\hline Bintang 1 & 45,95 & 44,68 & $-1,27$ \\
\hline Bintang 2 & 49,83 & 41,01 & $-8,82$ \\
\hline Bintang 3 & 55,40 & 43,95 & $-11,45$ \\
\hline Bintang 4 & 54,37 & 52,05 & $-2,32$ \\
\hline Bintang 5 & 42,77 & 45,30 & 2,53 \\
\hline Total & 51,40 & 45,28 & $-6,12$ \\
\hline
\end{tabular}

Menurut Badan Pusat Statistik (2020) menunjukkan bahwa pada bulan Januari 2020 TPK (Tingkat Penghunian Kamar) hotel bintang di kota Semarang mengalami 
Syaiful Ade Septemuryantoro, Potensi Akulturasi Budaya dalam Menunjang Kunjungan Wisatawan di Kota Semarang

penurunan apabila dibandingkan dengan TPK pada Bulan Desember. TPK bulan Januari 2020 sebesar 45,28 persen sedangkan bulan Desember 2019 TPK sebesar 51,40 persen, hal ini dikarenakan pada Bulan Desember merupakan masa peak season sementara TPK tertinggi pada bulan Januari 2020 menunjukkan angka 52,05 persen pada hotel bintang empat sedangkan TPK terendah ada sebesar 41,01 persen pada hotel bintang dua. TPK hotel bintang di kota Semarang dapat dilihat pada tabel 3 . Sedangkan rata-rata lama menginap pengunjung hotel pada bulan Januari 2020 sebesar 1,22 malam, apabila dibandingkan dengan rata-rata lama menginap di bulan Desember 2019 terdapat kenaikan sebesar 0,02 poin. Kunjungan wisatawan mancanegara yang menginap di hotel pada bulan Januari tercatat sebesar 1,40 poin yang mengalami kenaikan 0,12 poin, sedangkan wisatawan domestik sebesar 1,22 malam. Rata-rata lama menginap tamu hotel bintang dapat dilihat pada tabel 2 .

Tabel 4. Rata-rata Lama Menginap Tamu Hotel Bintang Periode Desember 2019- Januari 2020. [Sumber : https://semarangkota.bps.go.id/diakses 01 Maret 2020]

\begin{tabular}{ccccccc}
\hline Kelas Hotel & \multicolumn{3}{c}{ Desember 2019 } & \multicolumn{3}{c}{ Januari 2020 } \\
\cline { 2 - 6 } & Asing & Indonesia & Rata & Asing & Indonesia & Rata \\
\hline Bintang 1 & $\mathbf{1 , 0 0}$ & $\mathbf{1 , 0 7}$ & $\mathbf{1 , 0 9}$ & $\mathbf{1 , 5 7}$ & $\mathbf{1 , 1 5}$ & $\mathbf{1 , 1 5}$ \\
Bintang 2 & $\mathbf{1 , 0 6}$ & $\mathbf{1 , 2 2}$ & $\mathbf{1 , 2 0}$ & $\mathbf{1 , 2 6}$ & $\mathbf{1 , 1 9}$ & $\mathbf{1 , 2 9}$ \\
Bintang 3 & $\mathbf{1 , 4 3}$ & $\mathbf{1 , 2 1}$ & $\mathbf{1 , 2 4}$ & $\mathbf{1 , 5 3}$ & $\mathbf{1 , 2 1}$ & $\mathbf{1 , 2 2}$ \\
Bintang 4 & $\mathbf{1 , 3 3}$ & $\mathbf{1 , 1 9}$ & $\mathbf{1 , 2 0}$ & $\mathbf{1 , 4 7}$ & $\mathbf{1 , 2 7}$ & $\mathbf{1 , 2 7}$ \\
Bintang 5 & $\mathbf{1 , 3 1}$ & $\mathbf{1 , 1 6}$ & $\mathbf{1 , 1 7}$ & $\mathbf{1 , 2 9}$ & $\mathbf{1 , 4 6}$ & $\mathbf{1 , 4 5}$ \\
\hline Total & $\mathbf{1 , 2 8}$ & $\mathbf{1 , 1 8}$ & $\mathbf{1 , 2 0}$ & $\mathbf{1 , 4 0}$ & $\mathbf{1 , 2 2}$ & $\mathbf{1 , 2 2}$ \\
\hline
\end{tabular}

Bandara Ahmad Yani sebagai bandara internasional kota Semarang merupakan pintu masuk wisatawan yang akan mengunjungi kota Semarang tercatat pada bulan Januari 2020 sebesar 2.235 kunjungan tentunya mengalami penurunan apabila dibandingkan dengan bulan Desember 2019 sebesar 2.626 kunjungan yang berarti terjadi penurunan 14,92 persen, dari data tersebut diketahui bahwa kunjungan wisatawan mancanegara pada Januari 2020 tercatat warga malaysia sebanyak 849 
kunjungan, Singapura 279 kunjungan dan Cina sebesar 113 kunjungan, India 77 kunjungan, Amerika Serikat 63, Australia 51 kunjungan, Korea Selatan 36 kunjungan, Inggris 25 kunjungan, Jepang 22 kunjungan, Belanda 21 kunjungan, lainnya sebesar 699 kunjungan. Bulan Desember 2019 tercatat kunjungan warga Malaysia 891 kunjungan, Singapura 404 kunjungan, Cina 138 kunjungan, India 62 kunjungan, Amerika Serikat 41 kunjungan, Australia 29 kunjungan, Sri Langka 26 kunjungan, Jerman 21 kunjungan, Belanda 21 kunjungan, Jepang 20 kunjungan dan lainya 974 kunjungan. Perbandingan kunjungan wisatawan yang datang masuk melalui bandara Ahmad Yani dapat dilihat pada Grafik 2.

\section{Grafik 2. Perbandingan kunjungan wisatawan yang datang melalui bandara Ahmad Yani} [Sumber : https://semarangkota.bps.go.id/diakses 01 Maret 2020]

\section{SIMPULAN}

Kota Semarang sebagai kota multikultural budaya yang di dalamnya terdapat campuran dari 3 etnis yaitu etis Jawa, etnis Arab, dan etnis Tionghoa, ketiga budaya yang beragam tersebut berakultrasi dan membentuk suatu akulturasi budaya baru yang berupa kesenian tari yaitu gambang semarang, makanan khas Semarang yaitu Lunpia dan tradisi-tradisi yang ada seperti festival Imlek, Cheng Ho, Dugderan. Semarang tidak hanya menonjolkan sisi metropolitannya tetapi juga budaya yang kental sehingga kota Semarang merupakan salah satu tempat untuk wisata karena letaknya yang strategis di antara Jawa Timur dan Jawa Barat serta adanya akses bandara internasional Ahmad Yani memungkinkan wisatawan mancanegara maupun wisatawan domestik mengunjungi kota Semarang. Dilihat dari jumlah pengunjung yang mengunjungi kota Semarang dalam periode Januari 2020 menunjukkan bahwa 
Syaiful Ade Septemuryantoro, Potensi Akulturasi Budaya dalam Menunjang Kunjungan Wisatawan di Kota Semarang

Tingkat hunian kamar (TPK) mengalami penurunan 6 persen apabila dibandingkan dengan periode Desember 2019, hal ini dikarenakan pada waktu Desember 2019 merupakan peak season sementara pada bulan Januari 2020 merupakan masa low season. Rata-rata lama menginap tamu hotel bintang di kota Semarang menunjukkan terjadinya kenaikan 0,02 poin tentunya hal ini merupakan kabar yang sangat bagus bagi pariwisata di kota Semarang. Adanya akulturasi budaya di kota Semarang dapat meningkatkan kunjungan wisatawan baik yang wisata religi, wisata kuliner, maupun Wisata budaya yang semuanya dapat kita temukan di kota Semarang. Bandara internasional Ahmad Yani yang ada di kota Semarang merupakan salah satu akses keluar masuknya wisatawan mancanegara terbukti pada Januari 2020 menunjukkan bahwa warga negara Malaysia merupakan jumlah wisatawan tertinggi, disusul Singapura dan kemudian yang ketiga adalah Cina. Jumlah wisatawan Malaysia dan SIngapura tentunya tidak lepas dari adanya penerbangan langsung dari kedua kota tersebut yaitu di Semarang ke Kuala Lumpur dan Semarang ke Singapura, sehingga turut serta andil dalam meningkatkan pariwisata di kota Semarang

\section{REFERENSI}

Badan Pusat Statistik. (2020). Statistik Perhotelan Kota Semarang: Badan Pusat Statistik

Koentjaraningrat. (2009). Membangun Mentalitas dan Pembangunan, Jakarta: Gramedia Pustaka Utama

Muspriyanto, Edy. (2006). Semarang Tempo Doeloe; Meretas Masa, Semarang: Terang Publishing.

Septemuryantoro, Syaiful Ade. (2017). Potensi Wisata Budaya Jalur Gula dalam Menunjang Kenaikan Kunjungan Tamu Hotel di kota Semarang. Lite Volume 13. Semarang: Fakultas Ilmu Budaya, Universitas Dian Nuswantoro.

Supramono. (2007). Makna Warak Ngendog dalam Tradisi Ritual Dugderan di kota Semarang, Tesis: Universitas Negeri Semarang.

Triyanto. (2013). Warak Ngendhog: Simbol Akulturasi Budaya pada Karya Seni Rupa, Jurnal Komunitas, Edisi 5, Volume 2.

https://sampookong.co.id/, diakses 1 Maret 2020

https://semarangkota.bps.go.id/diakses 01 Maret 2020 